\title{
Reading habits and its effect on academic writing skill: a study of master degree students
}

\author{
Khoirunnisa $^{1, *}$, ida dwi safitri ${ }^{2}$ \\ ${ }^{12}$ Faculty of Teacher Training and Education Sebelas Maret University, Indonesia \\ ${ }^{1}$ eannisanisa662@gmail.com *; ${ }^{2}$ idadwisafitri@gmail.co \\ * corresponding author
}

\section{ARTICLE INFO}

Article history

Received September 08, 2017

Revised January 15, 2018

Accepted March 20, 2018

\section{Keywords}

Reading Habit

Academic Writing

ELT

Case Study

\begin{abstract}
Nowadays, students centered became a popular strategy in English Language Teaching (ELT). Teacher preferred to become a facilitator in the learning activity. Thus, as the learner, students should do an activity that had a big effect on their learning process. Reading was one of the important activity that had a great advantage to increase students writing skill. They should take reading as their habitual activity to get a significant improvement of learning achievement. In the context of higher education, reading activity was a basic requirement to start an activity in academic work such as writing a scientific journal. Through reading, they could get new information from the text. Then, it could be synthesized, evaluated, and implicated as the prior knowledge or supporting information in their writing. The aim of this study was to examine the reading habit of master degree students' and its effect on their academic writing skill. Twenty students from the master degree of Sebelas Maret University, Indonesia were selected to participate in the study.The data collected through an e-survey analyzed qualitatively. The finding indicated reading habit was crucial for students' academic writing skill. Furthermore, the conclusion discussed the implication of the finding in relation with teaching advanced learner.
\end{abstract}

This is an open access article under the CC-BY-SA license.

\section{Introduction}

Recently, student-centered became a popular strategy in English Language Teaching. The students had a big role in increasing their skill in English. The student should be an independence people that explored many things to be a knowledge. One of the exploring activity was reading. Reading was an activity to collect information or to find knowledge. It was one of the most important skills in English. Students could continue to the next level of English skill for instance: writing, if they have reading many sources.

As the key concept of getting information, reading provided an experience that made people linked without leasing in place, date, and time (Noor, 2011: 2). Usually, students who had good reading habit also had the good academic achievement. It happened because reading habit gave the student experience in recording information. Reading should be the student's habit because reading could promote good comprehension in acquiring knowledge based on self-experience. (Acheaw and Larson, 2014: 2). Reading many sources should be done continuously because it was the basic requirement of starting writing. The source of reading can be taken from a book, newspaper, magazine, article, journal, internet, etc. Johari,et.al. stated that reading activity was very valuable in our life because every day we found much information about texts. It was in line with Krashen (2004), he maintained that reading effectively and continuously could effect and enhance student 
performance in the academic skill such as grammar, vocabulary, spelling, reading, and writing (cited in Johari, et.al, 2013: 19).

In order to academic writing, reading played essential role in constructing an idea. The readers were free to develop their own interpretation of what they read. They could write the interpretation in their own language in order to make written text. Despite the idea was influenced by the text they have read, the formulation of delivering text was still different.

Furthermore, this study was conducted to examine the reading habits of master degree students' and its effect on their academic writing skill. The finding would provide the importance of students' reading behaviors and awareness on the role of reading toward the skill of academic writing.

\section{RELATED THEORIES}

Reading was an action cognitive process of interacting with print and monitoring comprehension to establish meaning (Scheiner cited in Kustaryo, 1988). Heilman said that reading was not the simple sum of its parts because in every case the reader must be considered in the process and each reader was unique (Heilman, 1967: 3). Reading was a complex process of acquiring knowledge. It required the students to have a good cognition strategy functions to know the organization, heading, and summary of the text. It also requires repertory of reading skill such as extensive reading (to know the information deeply), skimming (to know the general ideas), scanning (to know the detail information), and so on (Birch, 2002: 128). It meant that the reader not only understood printed materials but also must have the background knowledge of the text, so understanding a written material would be easier for them.

Moreover, Aebersold and Field (1997) stated that reading was something that people looked at the text and assigned meaning to the written symbols in that text, further, the text and the reader were the two physical entities necessary for the reading process to begin. The reader should be his knowledge of the language, knowledge of the writing system, and ability to interpret and to get meaning from the text.

In the term of reading scientific article/essay, the readers needed to have an appointment with critical reading because digging essay's information could not be executed instantly. They had to read the whole text not the piece of the paragraph. Sometimes habit of reading essay proposed the reader to be a critical one then helped them to draw the main point easily. It happened because they knew well the common structure of essay itself (Wall and Wall, 2005: 200).

According to Gardiner, reading habit could promote students productivity and creativity (Gardiner, 2005: 128). Habit itself meant that the action practice which did continuously until it became a pattern of behavior (Carter in Elliyina, 2012: 12). The students with the good habit of reading would be easier to understand the meaning of the written material. Students should have a good habit of reading because students could get a lot of information from what they have read. It can help students improve their knowledge of English.

In the accordance with academic writing skill, reading played essential part in the writing process. Without reading, the writing process would not run well. As we knew that writing was a process of producing a final product of student proficiency in learning the language. Producing a writing product was required long process because writing had some sequential steps that should be passed. Flower and Hayes 1980 in Tuan stated that writing was a complex process of constructing thought or idea to deliver meaning or message of the text (cited in Tuan, 2012: 489). In line with the previous expert, Nunan explained that writing was a complexity of cognition process maintaining critical effort to overcome the idea in long period (Nunan, 1999: 273) In higher education for instance: university level, writing was an important skill that should be master well by the student as the requirement in doing an assignment. Bailey stated that academic writing was formulated to the students at the medium level of universities in order to do task or assignment in particular coursework. Academic writing not only required the students to have complexity in vocabulary but also to learn the style of referencing and organizing text (Bailey, 2003: 1).

Academic writing skill had integration with reading because reading was the step of writing process which was functioned to collect information. In relation to academic writing, for instance: 
essay, reading was an important activity that should be done by students. They should read many appropriate sources that had similarity with the text they wanted to write. It would help them to construct their own theory based on some references. Crimmon said that before writing a critical essay, we should do some steps such as reading related work. He added that usually understanding text was not easy; sometimes we needed to read in many times (Crimmon, 1975: 189).

In line with Crimmon, Bailey explained that student should beware in choosing most appropriate source in assess reading a text. It was important because after choosing it, they should select relevant area of text to keep a record for references. Thus, they could synthesize theory from some sources by paraphrasing or summarize (Bailey, 2003: 2).

There were some findings in related studied that dealt with reading and reading habit: 1 . Reading habits had a direct relationship to academic performance. (Acheaw and Larson, 2014: 19); 2. Reading materials had advantages in enhancing and constructing an idea of writing. Both of student and teacher had a high percentage in choosing reading as the suggestion in teaching and learning writing (Tuan, 2015: 498); 3. Reading materials associated with academic work would be regarded as an importance for study (Noor, 2011: 6).

\section{Method}

This study aimed to examine the reading habit of master degree students' and its effect on their academic writing skill. The design of this study was qualitative research in the form of case study. The case study was applied to explore particular phenomena deeply by using extensive data collection (Creswell, 2012: 465, Fraenkel, et. al, 2012: 434).

\section{Participant}

Twenty students from the master degree at Faculty of Teachers Training and Education, Sebelas Maret University, Indonesia were selected to participate in the study. There were 6 males and 14 females participants of ages that ranged between 22-31 years old. They were enrolled in an academic writing program that was a required subject offered by English Education Study Program.

\section{Data Collection}

The data would be collected through an e-mail survey consisted of some questions related to the students' reading habit, academic writing and also its effect on their writing skill. As the effect of expanding technology, e- mail survey became a popular form of data collecting technique that could be used effectively and efficiently (Creswell, 2012: 220)

\section{Data Analysis}

The collected data would be analyzed and interpreted qualitatively. The researcher analyzed the data based on Creswell theory. There were six common steps in analyzing data such as 1. Prepared and organized the data; 2. Engaged data exploration through a coding process; 3. Developed general data description used the codes; 4. Narrated and visualized the findings; 5.Reflected personally and theoretically the result using an interpretation of the meaning; 6 . Conducted strategies to validate the findings (Creswell, 2012: 236)

\section{Findings and discussion}

To address the research question, this study used data from e-mail survey toward students' reading habit and their academic writing. There were 25 questions consisted of students' personal identity, students' reading habit, and students' skill on academic writing.

The questions about personal identity consisted of students' names, age, gender, department, semester. All of them were first semester students' of master degree program on English Education Study Program who followed academic writing. Most of the participants were 23 years old males. 


\section{Students Reading habit}

The Participants had various respond in answering how much they like reading. The found that $50 \%$ students like reading, $25 \%$ students like reading so much, $20 \%$ like reading enough, and the rest do not quite like reading. It showed that majority of the participant like reading because only a few participant $5 \%$ who had not preference in reading activity.

\section{Reading Frequency}

Related to the frequency, most of the participants had the high frequency in reading. Frequency is the special aspect of reading. It not only promoted students' vocabulary and knowledge, but also their skill in critical reading simultaneously. Each student had a distinction in saving their reading time but most of them could be categorized into diligent students because of the reading frequency. It also meant that they had a reading habit. Every day, they spent their time between 15-60 minutes in reading $(80 \%)$. Even there were $15 \%$ participants read more than 60 minutes every day. Only a few participants $(5 \%)$ read less than 15 minutes.

\section{Types of Reading Material}

Moreover, the participants read many kinds of reading source. Almost of them read printed book, e-book, website, newspaper, etc. but the highest percentage of reading material $(65 \%)$ was from the electronic material such as website and e-book. In master degree program, it would be expected that the students would prefer to read course material from the books but the finding showed the opposite. The most favorite reading material was the website then followed by e-book, printed book, others kind. It showed that reading e-material from internet or computer was the most popular reference in the master degree program.

This phenomenon also happened in many previous studies related to reading habit or reading activity. A study conducted by Noor revealed that the highest percentage of students $88 \%$ liked to read internet materials (Noor, 2006: 6). It was also found in Shen study that there were $47 \%$ students used their time more than 3 hours to online while 57\% used to online $1-2$ hours. It meant that reading by the electronic device was the very easier thing to do and they were always available to take their time in reading that material. The rest of the participants $(20 \%)$ preferred to read other sources of the book such as story and comic. It was an interesting finding because in the master degree program still existed the student who liked story and comic very much whereas it usually happened in the children age.

\section{Reason for Reading}

Table 1. The Reason for Reading

\begin{tabular}{cc}
\hline Reading Reason & Percentage \\
\hline Necessity & $70 \%$ \\
Hobby & $15 \%$, \\
Pleasure & $15, \%$ \\
\hline
\end{tabular}

In the term of the reasons for reading, this study found three types of reason for instance: the necessity of particular information, hobby, and the pleasure of entertain. The entire participant read because of them. No one read because of pressure from other people. The great quantity of participant (70\%) chose necessity as the reason, and then 33\% participant chose hobby and pleasure as the reason. Based on the reason above, it meant that they had a good preference in reading activity. They realized that reading was a necessity in life. As the result of reading activity, they not only got a lot of information to increase their knowledge but also got a pleasure dealt with the hobby.

\section{Necessity of Reading}

Reading could not be separated from student activity. They had to read as much as possible and as fast as possible. It had a close relationship with their reason for reading. They have realized what 
important reading is. It was showed in the finding of reading necessity. $40 \%$ participant agreed that reading was very important for them, $40 \%$ participant agreed that reading was important for them, and $20 \%$ participant agreed that reading was important enough.

\section{Academic Writing Skill}

In accordance with writing academic skill, this study found some fact based on the e-survey such as preference and interest, and types of academic work. It was summarized from five questions related to academic writing skill.

\section{Students' Interest of Academic Work}

The finding showed that the participants had good interest to write academic work. $35 \%$ participant interested in writing academic work, and $40 \%$ more interested enough to do this work. Thus, $15 \%$ participant interested very much, and the rest did not interest enough in doing this work.

The entire participant ever wrote this kind of academic writing. Around $65 \%$ of the participant ever wrote more than 3 academic works. Based on the finding above, it meant that the students of master degree program realize that writing academic work can promote pleasure because commonly academic work proposed to overcome the problems in many aspects of society or to get the solution of appeared problem in recent time. Automatically they also helped others to build better future.

\section{Types of Academic Work}

Table 2. Types of Academic Work

\begin{tabular}{|c|c|}
\hline Types & Percentage \\
\hline Essay & $40 \%$ \\
\hline Article & $10 \%$, \\
\hline Manuscript & $15 \%$ \\
\hline Journal & $10 \%$ \\
\hline Thesis & $5 \%$ \\
\hline
\end{tabular}

There are some types of academic work such as essay, article, journal, manuscript, thesis, etc. This type was categorized based on the writing purpose and organization. Every participant had their own preference in writing those types. The most common type written by master degree students was the essay $(40 \%)$. Essays also become the most favorite type chose to write. It happened because the essay was the simplest form of academic work. Another work that had a high percentage to be written was journal $(30 \%)$. It had the high percentage because of the importance. As the advanced learners, master degree students required writing journal and publish it in the international publication.

\section{Reading Habit and Its Effect on Academic Writing Skill}

Academic writing skill was influenced by students reading habit. The students who had a good reading habit they also had good skill in academic writing. This statement has known prominently in the academic environment.

This study provided some finding of reading habit and it effects on academic writing skill. There are some questions about reading and writing. The question consisted of reading habit, reading frequency, reading time, reading reference, reading effect, and reading importance. Thus, it was sum up into some terms.

\section{Frequency of Reading References}

Reading references became a crucial activity that should pass by the writer before starting writing. There are some advantages would get if the writer read material first before starting writing such as promoting ideas, enhancing information, constructing rationale, and collecting source. Besides that, the paraphrasing activity of authors' ideas became easier to do.

This study found that the entire participants had reading habit before they start writing. Most of them put reading as the important part in writing academic work. $50 \%$ participant stated that they 
frequently read the references they want to write. $10 \%$ was the percentage of the participant who always read references before starting writing. Thus, $40 \%$ participant stated that they were frequently enough in reading references. Moreover, almost of the participants prepared the specific time used to read references. They were around $85 \%$ while, the rest of the percentage did not do that.

In addition, they could spend more than 20 minutes per day in reading the reference. $70 \%$ participant used more than 20 minutes to read references. Some of them could spend their time to read more than one hour. Only a few participants spent the time to read less than 20 minutes.

Table 3. $\quad$ Frequency of Reading References

\begin{tabular}{|c|c|}
\hline Types & Percentage \\
\hline$<\mathbf{2 0}$ Minutes & $30 \%$ \\
\hline 20-60 Minutes & $55 \%$, \\
\hline$>\mathbf{6 0}$ minutes & $15 \%$ \\
\hline
\end{tabular}

\section{Type of Reading Reference}

In the term of academic writing, reference played important role in strengthening the work. The more the references the more strengthen the work. In other words, the student should collect many sources of reference to make their work more qualified. Reference was the requirement of writing academic work. The result will be acceptable if the writer wrote many references related to their work.

This study found that the participants used many references to support their writing. 55\% participant usually read more than 4 references while the rest read less than 4 references. Moreover, the journal was the reference that had the highest percentage $(55 \%)$. They prefer to read journal because the journal was the reference that provided specific issue related to the particular field. It would make the reader focus only on their field. Besides that, they also read e-book/ printed book as the references $(20 \%)$. The additional references they read were the article and internet material $(25 \%)$. No one read newspaper/magazine as the references to support their writing. The complete percentage could be seen in this following table:

Table 4.

The Reading References

\begin{tabular}{|c|c|c|}
\hline Types & Number & Percentage \\
\hline Journal & 11 & $55 \%$ \\
\hline E-book/ Printed Book & 4 & $20 \%$, \\
\hline Article & 3 & $15 \%$ \\
\hline Internet Material & 2 & $10 \%$ \\
\hline Newspaper/ Magazine & 0 & $0 \%$ \\
\hline
\end{tabular}

\section{Reading habit Effect toward Academic Writing Skill}

Reading had a big effect toward academic writing skill. The quality of writing product showed how many times writer read. In academic writing, reading references encouraged the writer to be a critical thinker so that, the quality of writing product would be more acceptable. Moreover, If it became a lifelong reading, it would make students be more critic, creative, and productive writer (Gardiner, 2005: 128).

The finding of this study showed that the major participants had the same appointment. $60 \%$ participant thought that reading habit provided a great effect in their academic writing skill. $20 \%$ participant thought that reading gave big effect and the rest $20 \%$ participant thought that reading had sufficient effect in their academic writing skill.

In addition, they sought that reading was very important for them. It built up inspiration/ ideas, promoted critical analysis, enhanced knowledge, enriched diction, collected detail information, strengthened theory, improved writing quality, etc. 


\section{Reading Habit Effect Toward Academic Writing Skill}

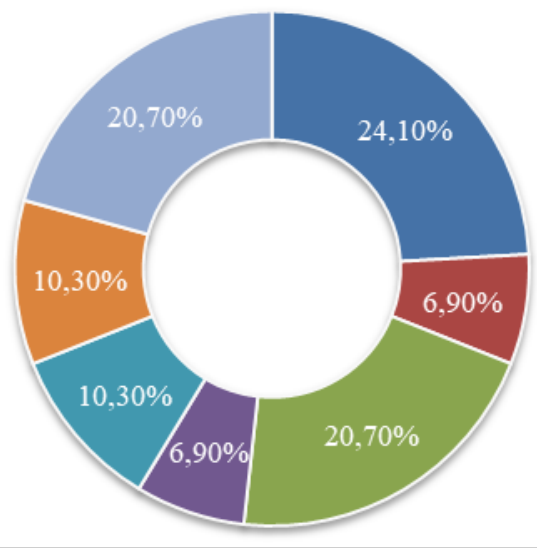

- Built up inspiration/ ideas

- Promoted critical analysis

Enhanced knowledge

- Enriched diction/ vocabulary

- collected detail information

- Streghtened theory

- Improved writing quality

\section{Conclusion}

This case study examined the reading habit and its effect on academic writing skill of master degree students. These findings provided empirical evidence toward students who liked reading and also like writing. The interesting finding was the student views about reading habit toward their academic writing skill. The entire students had the same idea about the effect of reading habit. Reading habit could build up inspiration/ ideas, promoted critical analysis, enhanced knowledge, increased diction, got detail information, strengthened theory, and improved writing quality, and so on. It revealed reading habit was important for master degree program because they were required to write journals.

In addition, the result of this study showed that students of master degree program agreed that reading was a necessity. Thus, to fulfill the necessity, they preferred to read e- material such as ebook and website. That preference was caused by the developing of digital technology. This made the student download and access freely.

The finding of this study offered several implications for teaching academic writing of master degree students in advanced learner context. First, the lecturer should be aware in giving the instruction of academic writing. Consider their understanding about academic writing (sufficient or not). Second, the lecturer should give feedback to the student in the process of writing academic work. The lecturer should teach the steps to write qualified academic work. Third, the lecturer should give the student task to read some journal reference to promoting their academic writing skill. The last, the lecturer should provide a reading log to motivate students to practice reading habit.

\section{References}

Acheaw, Micheal Owusu and Larson, Agatha Gifty. (2014). Reading Habits Among Students and its Effects on Academic Performance: A Study of Students of Koforidua Polytechnic. Library Philosophy and Practice (e-journal): University of Nebraska-Lincoln.

Bailey, Stephen. (2003). Academic Writing, A Practical Guide for Student. New York: RoutledgeFalmer.

Bian, Xiaoyun and Wang, Xiaohong. (2016). Chinese EFL Undergraduate's Academic Writing: Rhetorical Difficulties and Suggestions. Indonesian Journal of Applied Linguistics, 6 (1), P. 20-29.

Brich, Barbara M. (2002). English L2 Reading: Getting to the Bottom. London: Lawrence 
Erlbaum Associates.

Carroll, Joyce Amstrong and Wilson, Edward. E. (1993). Act of Teaching, How to Teach Writing. USA: Teacher Ideas Press.

Creswell, J. (1998). Qualitative inquiry and research design: Choosing among five traditions. Thousand Oaks, CA: Sage.

Creswell, J. (2012). Educational Research: Planning, Conducting, And Evaluating Quantitative And Qualitative Research (4th ed.). Boston, MA: Pearson.

Fraenkel, Jack, R. et. al. How to Design and Evaluate Research in Education. New York: McGrawHill.

Gardiner, Steve. Building Student Literacy Through: sustained Silent Reading. USA: Association for Supervision and Curriculum Development.

Johari, Aiza, et. al. (2013). Students' reading practices and environments. Indonesian Journal of Applied Linguistics, 2 (1), P. 17-28.

Noor, Noorizah Mohd. (2011). Reading Habit and Preferences of EFL Post Graduates: A Case Study. Indonesian Journal of Applied Linguistics.

Nunan, David. (1999). Second Language Teaching and Learning. USA: Heinle \& Henle Publishers.

Starcher, Keith and Proffitt, Dennis. (2011). Encouraging Students to Read: What Professors Are (and Aren't) Doing About It. International Journal of Teaching and Learning in Higher Education, 23 (3), P. 396-407.

Stuart, Christian. (2008). Connecting Reading and Writing in Second Language Writing Instruction. Journal of English for Academic Purposes, 7 (1), P. 68-73.

Tuan, Trong Luu. (2012). Teaching Writing with Reading Integration. Journal of Language Teaching and Research, 2 (3), P. 489-499.

Wall, Amy, and Wall, Regina. 2005. The Complete Idiot's Guide to Critical Reading. USA: Alpha Book. 